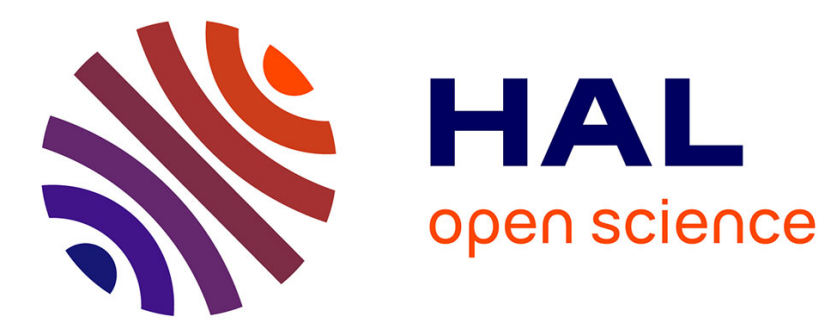

\title{
Dielectric measurements of liquid crystals
}

\author{
Z. Belarbi, G. Guillaud, M. Maitrot, J. Huck, J. Simon, F. Tournilhac
}

\section{To cite this version:}

Z. Belarbi, G. Guillaud, M. Maitrot, J. Huck, J. Simon, et al.. Dielectric measurements of liquid crystals. Revue de Physique Appliquée, 1988, 23 (2), pp.143-147. 10.1051/rphysap:01988002302014300 . jpa-00245757

\section{HAL Id: jpa-00245757 https://hal.science/jpa-00245757}

Submitted on 1 Jan 1988

HAL is a multi-disciplinary open access archive for the deposit and dissemination of scientific research documents, whether they are published or not. The documents may come from teaching and research institutions in France or abroad, or from public or private research centers.
L'archive ouverte pluridisciplinaire HAL, est destinée au dépôt et à la diffusion de documents scientifiques de niveau recherche, publiés ou non, émanant des établissements d'enseignement et de recherche français ou étrangers, des laboratoires publics ou privés. 


\title{
Dielectric measurements of liquid crystals
}

\author{
Z. Belarbi, G. Guillaud, M. Maitrot, J. Huck, J. Simon ( $\left.{ }^{1}\right)$ and F. Tournilhac $\left(^{1}\right)$ \\ Laboratoire Electronique des Solides, Université Claude Bernard, Lyon I, 43 bd du 11 Novembre 1918, 69622 \\ Villeurbanne Cedex, France \\ ( $\left.{ }^{1}\right)$ Laboratoire de Chimie Inorganique, CNRS (UA 429) E.S.P.C.I., 10 rue Vauquelin, 75005 Paris, France
}

(Reçu le 17 juillet 1987, accepté le 19 novembre 1987)

\begin{abstract}
Résumé. - Nous avons utilisé une nouvelle cellule permettant des mesures diélectriques sur de faibles quantités de cristal liquide. Cette cellule a été utilisée pour des mesures diélectriques du cyanobenzylidène $\mathrm{p}^{\prime}$ octyloxyaniline (CBOOA). Nous avons déterminé la permittivité complexe sous l'action d'un champ électrique continu et alternatif, ainsi que sous champ magnétique et ceci dans un grand intervalle de fréquences et de températures en phase nématique et smectique.
\end{abstract}

\begin{abstract}
A new measurement cell for very small quantities of liquid crystals is used for the determination of the complex permittivity of the cyanobenzylidene $\mathrm{p}^{\prime}$ octyloxyaniline (CBOOA). The dielectric behaviour in the nematic and smectic-A phase is given as a function of an applied electric field (static and alternative) as well as of a magnetic one within a large frequency and temperature range.
\end{abstract}

\section{Introduction.}

The electrical behaviour is relatively scarcely studied in the numerous papers relative to liquid crystals. Maier and Meier were the pioneers in the domain [1]. Nematic compounds with cyano substituents along their long molecular axis were studied in order to have twisted nematic displays with low threshold voltages, and other electronics or non linear optics applications [2-4]. The organic molecules have the advantage to possess very high polarizabilities. Barnik et al. [5] were the first to study the effect of second harmonic generation with a liquid crystal.

The molecules of cyanobenzylidene $p^{\prime}$ octyloxyaniline (CBOOA) possess a high permanent dipole moment due to the presence of a cyano group at the edge of the chain. This compound can be oriented by an electric or magnetic field and become non-centrosymmetric in the nematic and smectic phases. It is therefore necessary to determine the optimum values of electric field frequency and intensity to be used for second harmonic generation.

Dielectric measurements reflect both electronic and orientational polarizations. The knowledge of dielectric constants $\varepsilon_{\|}^{\prime}$ and $\varepsilon_{\perp}^{\prime}$ gives fruitful informations about the structure of the mesophase.

It can be very interesting to get special cells in order to be able to have precise measurements on some liquid crystals with a very small amount of material (some $\mathrm{mg}$ ).

The compound CBOOA is one of the most studied material for the smectic $\mathrm{A} \rightarrow$ nematic transition : the phase is smectic A between $73^{\circ}$ and $83^{\circ} \mathrm{C}$ and nematic between $83^{\circ}$ and $109^{\circ} \mathrm{C}$. This material presents a quasi second order transition [6] to the nematic phase and has a partially bilayered structure $[7,8]$. Many studies have been made with this compound : thermomechanical [6], elastic constant [9], transition nematic smectic and ultrasonic absorption $[10,11]$, mechanical intramolecular relaxation time, calorimetric and magnetic anisotropy [12], viscosity and magnetic measurements for $\mathrm{N} \rightarrow \mathrm{S}_{\mathrm{A}}$ transition [13], viscosity by NMR and DMR studies $[13,14]$. The DC conductivity versus temperature was given by Mircea-Roussel et al. [15]. The value of dielectric anisotropy of CBOOA is positive $(\Delta \varepsilon>0)$.

In the present work, the dielectric and elastic 
constants, and their variations with AC or DC voltage amplitude, magnetic field intensity and with temperature are given.

\section{Experimental.}

Cells are constituted of two microscope glass plates. These plates are attacked by fluorhydric acid, the depth depends on the processing duration and the acid concentration. The glass plates are then coated with chromium and gold thin films evaporated successively. The adherence of these electrodes is very satisfactory.

The cell thickness is determined from capacity measurements without liquid crystal. Sometimes a glass lens of large focal distance $(600 \mathrm{~mm})$ is used as lower electrode. A small quantity of studied material is adequate : a thickness of about $5 \mu \mathrm{m}$ is easily obtained (Fig. 1).

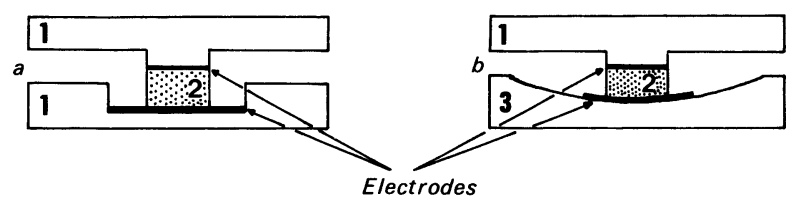

Fig. 1. - Measuring cells a) with two attacked glass plates, b) with an attacked glass plate and a lens, 1. glass plate, 2. liquid crystal, 3 . lens.

The sample cell is fixed in a flat copper box heated with paste fixed resistances (Foil Minco). The whole system is of reduced dimensions and can be introduced between the poles of an electromagnet.

The temperature of the cell is thermostated to $\pm 0.2^{\circ} \mathrm{C}$ and a platine resistance is used to test the liquid crystal temperature. The electrical connections are carefully realized to avoid parasitic impedances.

Dielectric measurements are performed using the cell as a capacitor of area $S=7.06 \mathrm{~mm}^{2}$ and of thickness $d=30 \mu \mathrm{m}$ in a large frequency range $\left(10^{-3}\right.$ to $\left.2 \times 10^{6} \mathrm{~Hz}\right)$ on cooling the sample.

The complex permittivity is given by :

$$
\begin{gathered}
\varepsilon^{*}=\varepsilon^{\prime}-j \varepsilon^{\prime \prime} \\
\text { with }: \varepsilon^{\prime}=C d / \varepsilon_{0} S \text { and } \varepsilon^{\prime \prime}=\varepsilon^{\prime} / R C \omega=\sigma / \omega .
\end{gathered}
$$

Measurements of the components of the complex permittivity in nematic and smectic phases are performed in two geometries : $\mathbf{E}, \mathbf{H} / / \mathbf{n}$ and $\mathbf{H} \perp \mathbf{n}$.

In the lower frequency range $\left(10^{-3}\right.$ to $\left.10 \mathrm{~Hz}\right)$ the capacitance and conductance are measured with a semi-automatic apparatus achieved in our laboratory [16].

From $100 \mathrm{~Hz}$ to $100 \mathrm{kHz}$, we used a General Radio 1610 bridge and from $10 \mathrm{kHz}$ to $2 \mathrm{MHz}$ an automatic HP 4275 bridge controlled by a microcomputer HP 85F.

\section{Results and discussion.}

The transition temperatures were determined from capacitance measurements for frequencies between $10 \mathrm{kHz}$ and $2 \mathrm{MHz}$ with heating and cooling rates of $0.5^{\circ} \mathrm{C} / \mathrm{mn}$ and from differential scanning calorimetry (D.S.C.). Capacity versus temperature is given in figure 2 for $f=10 \mathrm{kHz}$.

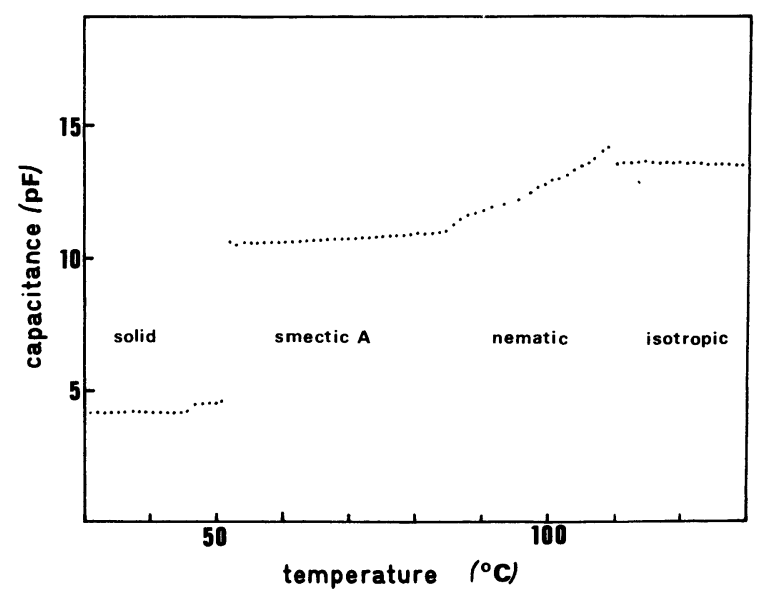

Fig. 2. - Capacity as a function of temperature at $f=10 \mathrm{kHz}$.

The correspondence between both methods is very satisfactory. Moreover the capacitance measurements allow the detection of the smectic $\mathrm{A} \rightarrow$ nematic transition.

The variation of the conductance $G(\omega)$ and capacity $C(\omega)$ are given versus frequency for some temperatures in figure 3 . The amplitude of the measurement electric field was about $100 \mathrm{mV}$ in order to avoid any orientation of the sample.

$\bar{\varepsilon}^{\prime}$ and $\bar{\sigma}(\omega)$ are given for the different phases in table I at a frequency $f=10 \mathrm{kHz}$.

Table I.

\begin{tabular}{ccccc}
\hline Phase & Isotropic & Nematic & Smectic A & Crystal \\
\hline$T\left({ }^{\circ} \mathrm{C}\right)$ & 130 & 105 & 60 & 20 \\
$\bar{\varepsilon}$ & 6 & 5 & 4.2 & 2.2 \\
$\bar{\sigma}(\Omega . \mathrm{cm})^{-1}$ & $1.2 \times 10^{-7}$ & $5.9 \times 10^{-8}$ & $9 \times 10^{-9}$ & $1.7 \times 10^{-12}$
\end{tabular}

We observe two distinct domains in the curves: the high frequency range $\left(10^{3}-10^{5} \mathrm{~Hz}\right)$ where the capacitance and conductance are constant, which reflects the bulk properties and the lower frequency range $\left(10^{-3}-10^{3} \mathrm{~Hz}\right)$ corresponding to ionic phenomena. In fact, the important increase of the capacitance at low frequencies is due to the presence of ionic impurities near the electrodes (blocking effect). To avoid this blocking effect, the dielectric 


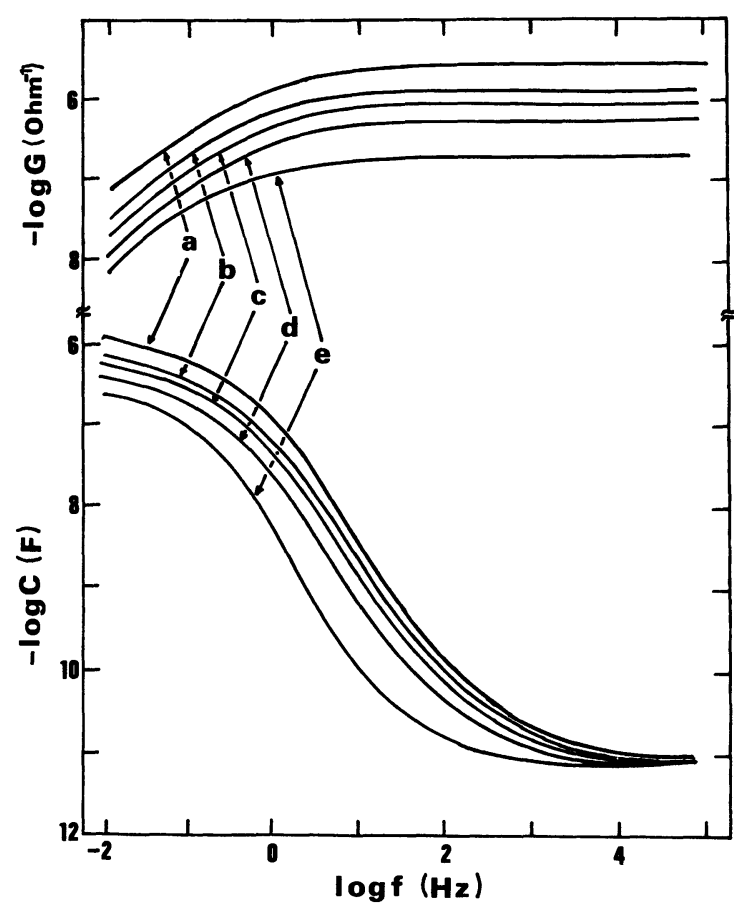

Fig. 3. - Dielectric spectra (conductance and capacitance) for various temperatures a) $T=130{ }^{\circ} \mathrm{C}$; b) $T=$ $105^{\circ} \mathrm{C}$; c) $T=95^{\circ} \mathrm{C}$; d) $T=80^{\circ} \mathrm{C}$; e) $T=60^{\circ} \mathrm{C}$.

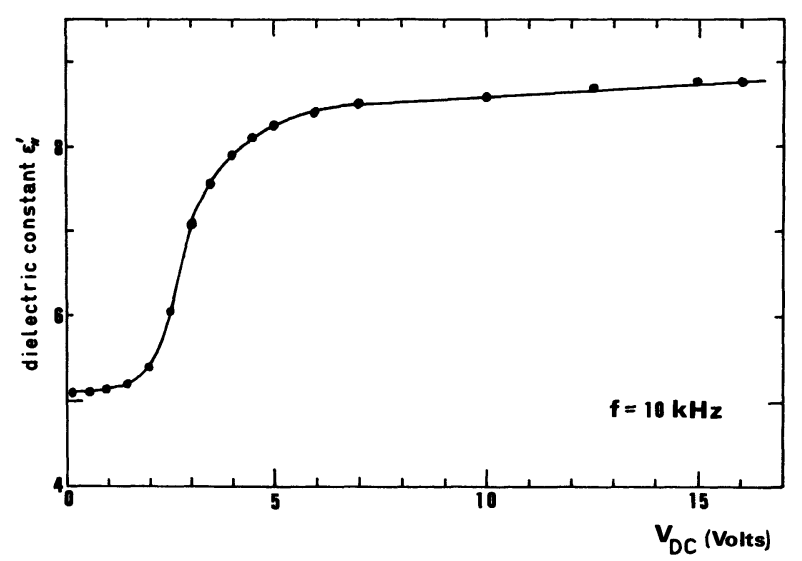

Fig. 4. $-\varepsilon i^{\prime}$ as a function of $V_{\mathrm{DC}}$ at $T=105^{\circ} \mathrm{C}$.

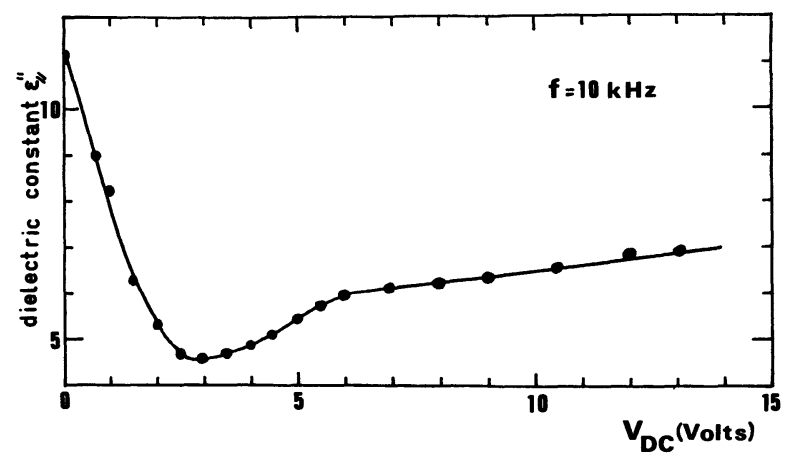

Fig. 5. $-\varepsilon_{1}^{\prime \prime}$ as a function of $V_{\mathrm{DC}}$ at $T=105^{\circ} \mathrm{C}$. measurements were performed in the following work at $f=10 \mathrm{kHz}$.

The variations of $\varepsilon_{\|}^{\prime}$ and $\varepsilon_{\mid \prime}^{\prime \prime}$ are given in figures 4 , 5,6 and 7 versus the amplitudes of DC and AC applied electric fields respectively at $T=105^{\circ} \mathrm{C}$ and $f=10 \mathrm{kHz}$.

The variation of the two dielectric constant components $\varepsilon \mid$ and $\varepsilon_{\perp}^{\prime}$ versus magnetic field intensity are given in figure 8 at $T=105^{\circ} \mathrm{C}$ and $f=10 \mathrm{kHz}$.

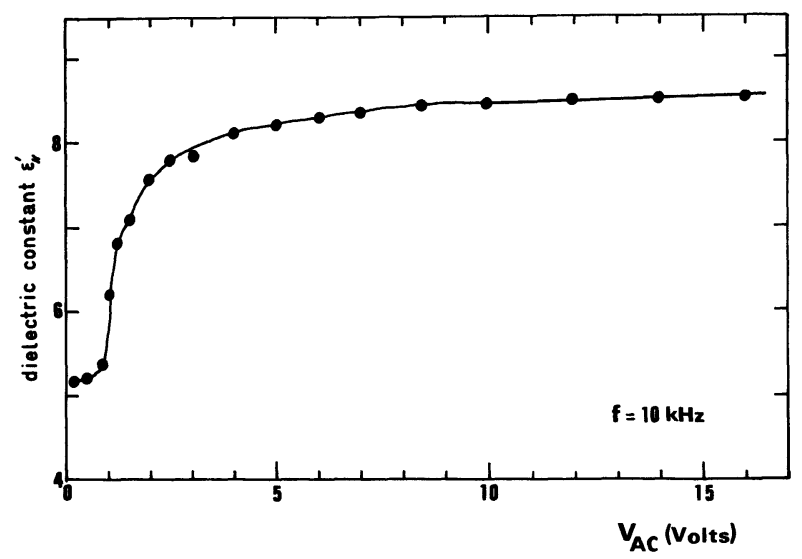

Fig. 6. $-\varepsilon_{i}^{\prime}$ as a function of $V_{\mathrm{AC}}$ at $T=105^{\circ} \mathrm{C}$.

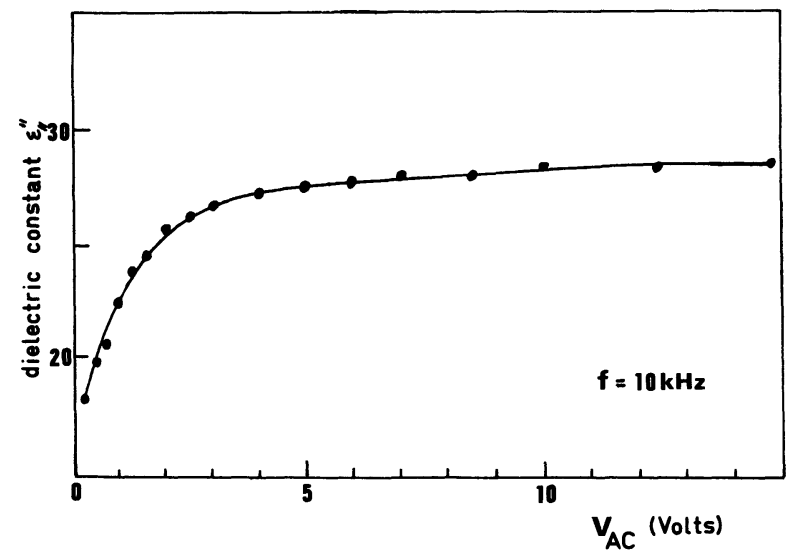

Fig. 7. $-\varepsilon_{\|}^{\prime \prime}$ as a function of $V_{\mathrm{AC}}$ at $T=105^{\circ} \mathrm{C}$.

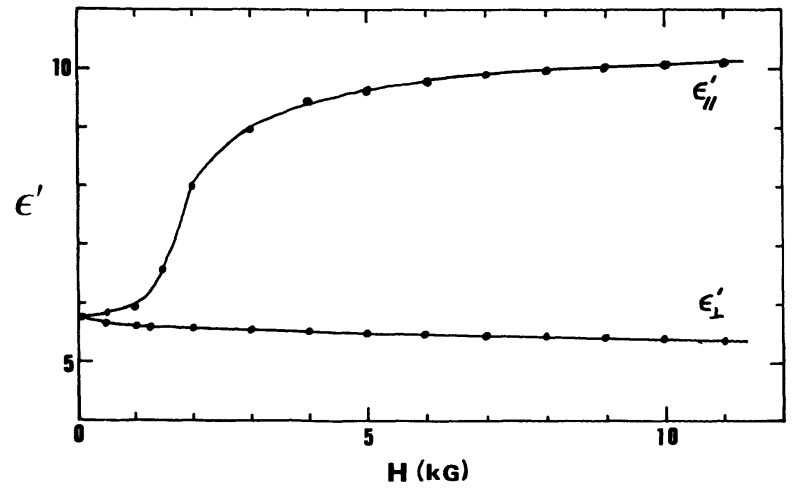

Fig. 8. $-\varepsilon_{\mid}^{\prime}$ and $\varepsilon_{\perp}^{\prime}$ as a function of magnetic field at $T=105^{\circ} \mathrm{C}$ and $f=10 \mathrm{kHz}$. 
The variation of constants $\varepsilon \|^{\prime}$ and $\varepsilon_{\perp}^{\prime}$ are given versus temperature at $f=10 \mathrm{kHz}$ under a magnetic field of $H=9 \mathrm{kGauss}$ in figure 9 .

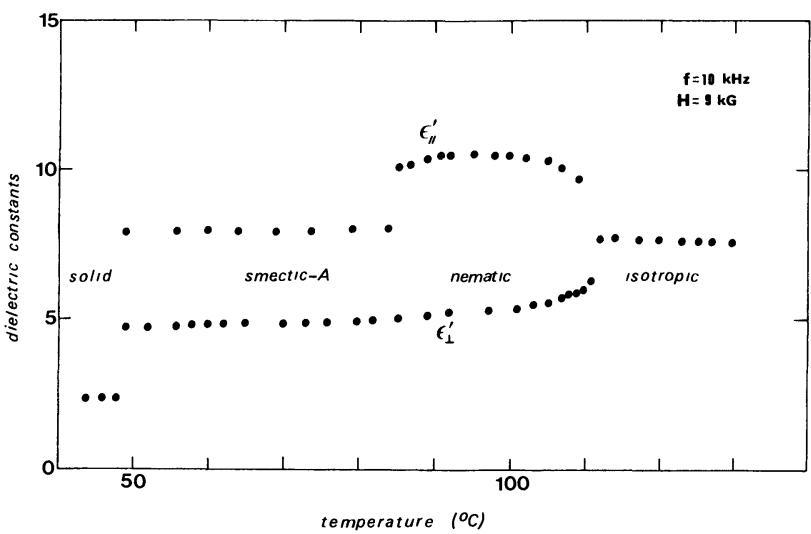

Fig. 9. $-\varepsilon_{i}^{\prime}$ and $\varepsilon_{\perp}^{\prime}$ as a function temperature at $f=$ $10 \mathrm{kHz}$ and $H=9 \mathrm{kG}$.

These dielectrical measurements allow the determination of the values of dielectric anisotropy $\Delta \varepsilon$, elastic constants and transport properties.

The parallel component of conductivity $\sigma_{\|}=$ $\varepsilon \|^{\prime \prime} \omega$ decreases up to voltages higher than the Freederiksz transition when a DC electric field or magnetic field induces a deformation in liquid crystal, and then increases slowly above a threshold field. A different behaviour is observed with $\mathrm{AC}$ voltage in this case, $\sigma_{\|}$increases whatever this voltage may be.

The values of the dielectric constant $\varepsilon^{\prime}$ in the isotropic phase and the dielectric anisotropy $\Delta \varepsilon$ one in the nematic phase are similar to those found by Billard et al. [17] (at $T=85^{\circ} \mathrm{C}, \Delta \varepsilon=5.5$ in the present work).

In the smectic range, however, these authors did not detect any dielectric anisotropy; this fact was probably due to desorientation in the sample. In our case, we observe continuity of $\varepsilon_{\perp}^{\prime}$ at the $\mathrm{S}_{\mathrm{A}} \rightarrow \mathrm{N}$ transition while $\varepsilon \|^{\prime}$ decreases strongly.

The same behaviour has been observed by Nagabhushan et al. [18] in the compound 4 OBCAB. The sharp drop in constant $\left.\varepsilon\right|^{\prime}$ is due to the effect of dimerisation [19] : in the smectic phase of CBOOA, the antiparallel correlation is stronger than in the nematic phase. In fact, a fraction of the molecules form quadripolar dimers by head to head association and cannot participate to dipolar effects. Engelen et al. [8] estimated the fraction of dipolar correlation at 0.5 .

It can be noticed that the slope of $\varepsilon \|^{\prime}$ versus $\left(V_{\mathrm{AC}}\right)^{-1}$ is linear and close to the slope of $\varepsilon \|^{\prime}$ versus
$\left(V_{\mathrm{DC}}\right)^{-1}$ with a much larger linearity range. This allows us to determine with accuracy the asymptotic value $\varepsilon \|^{\prime}(V \rightarrow \infty)=8.8$ and to obtain $\Delta \varepsilon=4.8$ at $H \rightarrow 10 \mathrm{kG}, T=105^{\circ} \mathrm{C}$ and $f=10 \mathrm{kHz}$.

With an applied magnetic field, the experimental results show that $\varepsilon_{\perp}^{\prime}$ is almost constant and very near $\bar{\varepsilon}$ (without orientation). It can be deduced that the molecules are in the planar alignment (director parallel to the electrodes) in the nematic phase without external force (see Fig. 8).

The value of the threshold voltage for the Freedericksz transition is $V_{\text {th }}=0.9 \mathrm{~V}$ and is rather weak for nematic compounds with cyano substituents along their long molecular axis.

The Freederiksz transition allows the calculation of the splay elastic constant $K_{11}$ from the threshold potential, with $\Delta \varepsilon>0$

$$
\begin{aligned}
V_{\mathrm{th}}=\pi & \left(K_{11} / \varepsilon_{0} \Delta \varepsilon\right)^{1 / 2} \\
K_{11} & =3.99 \times 10^{-12} \mathrm{~N} \\
\left(K_{11} / \Delta \chi\right) & =5.33(\text { C.G.S. }) .
\end{aligned}
$$

and

This value is close to that of Cheung et al. [20] obtained by optical measurements with an homeotropic orientation. These authors found $K_{11}=K_{33}$ (bend constant) at temperatures from $93{ }^{\circ} \mathrm{C}$ to the nematic-isotrope transition $\left(T=109^{\circ} \mathrm{C}\right)$.

Finally, from our measurements, we can deduce that the compound CBOOA possesses a high polarizability $(\Delta \varepsilon \approx 4.8)$, it can be completely oriented with an electric field strength higher than $3000 \mathrm{~V} / \mathrm{cm}$ (AC or DC) or by a magnetic field. On the other hand, we can avoid ionic phenomena with frequencies higher than $\approx 10 \mathrm{kHz}$.

\section{Conclusion.}

We presented in this paper the results of dielectric measurements of cyanobenzylidene $\mathrm{p}^{\prime}$ octyloxyaniline obtained with a new measurement cell, which allows us to determine dielectric constants with satisfactory precision. Our data for the nematic phase are in good agreement with these reported by Billard [17] but we observe a different behaviour in the smectic-A phase which may be explained by the partial dimerisation of the molecules. We have determined the optimum conditions of orientation and utilisation of the compound CBOOA as an organic material suitable for second harmonic generation.

\section{Acknowledgments.}

Z. Belarbi wishes to thank Mr. G. Massouras for precious discussions and help. 


\section{References}

[1] MAIER, W. and MeIER, G., Z. Naturforsch 16a (1961) 1200.

[2] Nicoud, J. F., Images de la Chimie, le courrier $d u$ CNRS Sup. $N^{\circ} 56$ (1983-1984) 29.

[3] Nicoud, J. F. and Twieg, R. J., Non Linear Optical Properties of Organic Molecules and Crystals, Eds. D. S. Chemla and J. Zyss (Academic Press) 1987.

[4] Chemla, D. S., Oudar, J. L., Jerphagnon, J., Phys. Rev. B 12 (1975) 4534.

[5] BARnik, M. I., Blinov, L. M., Dorozhkin, A. M., ShTYKov, N. M., Sov.Phys.JTP 54 (1981) 935.

[6] Ribotta, R., J. Phys. Colloq. France 37 (1976) C1/149.

[7] Chandrasekhar, S., Mol. Cryst. Liq. Cryst. 124 (1985) 1.

[8] Engelen, B., Heppke, G., Hopf, R., Schneider, F., Ann. Phys. 3 (1978) 403.

[9] BACri, J. C., J. Phys. Colloq. France 36 (1975) C1/123.

[10] Kiry, F., Martinoty, P., J. Phys. Colloq. France 37 (1976) C1/113.
[11] Bartolino, R., Sandieri, F., Sette, D., Slivinsk, A., J. Phys. Colloq. France 36 (1975) C1/121.

[12] Hardouin, F., Gasparoux, H., Delhaes, P., J. Phys. Colloq. France 36 (1975) C1/127.

[13] Wise, R. A., Olah, A., Doane, J. W., J. Phys. Colloq. France 36 (1975) C1/117.

[14] Deloche, B., Charvolin, J., J. Phys. Colloq. France 37 (1976) p. 1497.

[15] Mircea-Roussel, A., Léger, L., Rondelez, F., DE JEU, W. H., J. Phys. Colloq. France 36 (1975) C1/93.

[16] Guillaud, G., Rosenberg, N., J. Phys. Colloq. France E 13 (1980) 1287.

[17] Billard, J., Dubois, J. C., ZanN, A., J. Phys. Colloq. France 36 (1975) C1/355.

[18] Nagabhushan, C., Ratna, B. R., Shashidhar, R., Mol. Cryst. Liq. Cryst. 139 (1986) 209.

[19] Guillon, D., Skoulios, A., J. Phys. France 45 (1984) 607.

[20] Cheung, L., Meyer, R. B., Gruler, H., Phys. Rev. Lett. 31 (1973) 349. 